\title{
A CASE OF ADRENOCORTICAL ADENOMA PRODUCING 11-DEOXYCORTICOSTERONE (DOC) INDEPENDENT OF ACTH CONTROL.
}

\author{
Takashi Nagai, $\mathrm{MD}^{1)}$, Takashi Tomizawa, $\mathrm{MD}^{2)}$, Minoru Satou, $\mathrm{MD}^{2)}$, \\ Masatomo Mori, $\mathrm{MD}^{2)}$ \\ 1) Department of Internal Medicine, Public Tomioka General Hospital \\ 2) First Department of Internal Medicine, Gunma University School of Medicine
}

\begin{abstract}
A 31-year-old woman with left adrenocortical adenoma had hypertension, hypokalemia and low plasma renin activity (PRA) level. The plasma aldosterone and urinary 17-OHCS levels were within normal range. However, the plasma 11-deoxycorticosterone (DOC) level was elevated. Diurnal variation of DOC was absent. Dexamethasone administration suppressed ACTH and cortisol levels, but did not depress DOC level. Acute synthetic ACTH administration increased cortisol level, however, DOC level was unchanged. After removal of the tumor, her blood pressure, serum potassium, PRA and DOC levels were normalized. The high level of DOC caused an increase in blood pressure and was independent of ACTH control.
\end{abstract}

Key words: Hypertension, Hypokalemia, Plasma renin activity, ACTH control (Kitakanto Med.J. 49 (5) : 353 355, 1999)

\section{INTRODUCTION}

Excessive production of mineralocorticoid hormone, generally due to an overproduction of aldosterone, causes hypertension and hypokalemia. 11deoxycorticosterone (DOC), a precursor of corticosterone and aldosterone, has a weak mineralocorticoid action, but its overproduction can cause hypermineralocorticism in the absence of excessive production of aldosterone or cortisol ${ }^{1 \sim 3}$. DOC secretion from an adrenocortical tumor ${ }^{2,3)}$ are controlled by ACTH. We report here on a case of adrenocortical adenoma producing DOC without ACTH control.

\section{CASE REPORT}

A 31-year-old woman went though her second pregnancy and delivery in May. During her second pregnancy, her blood pressure ranged between 140/80 and $150 / 90 \mathrm{mmHg}$. She was admitted to our hospital in July, because of hypertension. Her blood pressure was $172 / 104 \mathrm{mmHg}$ and pulse rate, 74 beats per minute. Other physical examination results were negative.
Laboratory data were as follows: electrocardiogram showed $U$ waves. The serum sodium level was $141 \mathrm{mEq} / 1$; potassium, $1.9 \mathrm{mEq} / 1$ and chloride, $99 \mathrm{mEq} / 1$. The arterial $\mathrm{pH}$ showed slight alkalosis $(\mathrm{pH}$ $7.464)$ and base excess, $+6.6 \mathrm{mEq} / 1$. All of other chemical analyses were normal. Results of hormonal studies are summarized in Table 1 and 2. Basal plasma renin activity (PRA) was low, but blood levels of adrenocorticotropic hormone (ACTH), cortisol, progesterone, corticosterone, aldosterone and urinary excretion of 17-OHCS, 17-KS and catecholamine (such as urinary metanephrine) levels were within normal range. In contrast, DOC was remarkably high (Table 1). PRA failed to respond to 2 hour-upright posture after an intravenous administration of $40 \mathrm{mg}$ furosemide. Plasma levels of aldosterone and DOC were also almost unchanged (Table 2a). Plasma ACTH and cortisol levels showed daily fluctuation, but its fluctuation was not found in DOC levels. An administration of $1 \mathrm{mg}$ dexamethasone at $2300 \mathrm{~h}$ decreased plasma levels of ACTH and cortisol at $0600 \mathrm{~h}$ the next day, but, plasma level of DOC was unchanged (Table 2b).

Received : June 28, 1999

Address : TAKASHI NAGAI

Department of Internal Medicine, Public Tomioka General Hospital,

2073-1 Tomioka, Tomioka, Gunma, 370-2396, Japan 
Table 1 Laboratory data

\begin{tabular}{|c|c|c|c|c|c|}
\hline Date & $7 / 26$ & $8 / 12$ & $9 / 10$ & $11 / 28$ & \\
\hline Blood pressure $(\mathrm{mmHg})$ & $172 / 104$ & $160 / 100$ & $132 / 78$ & $132 / 80$ & \\
\hline Serum & & & & & $\langle$ normal range $\rangle$ \\
\hline $\mathrm{Na}(\mathrm{mEq} / 1)$ & 141 & 141 & 140 & 139 & $135-147$ \\
\hline $\mathrm{K}(\mathrm{mEq} / \mathrm{l})$ & 1.9 & 2.2 & 4.1 & 3.9 & $3.6-5.0$ \\
\hline $\mathrm{Cl}(\mathrm{mEq} / \mathrm{l})$ & 99 & 102 & 103 & 101 & $98-108$ \\
\hline \multicolumn{6}{|l|}{ Plasma } \\
\hline Renin activity $(\mathrm{ng} / \mathrm{ml} / \mathrm{hr})$ & 0.1 & 0.1 & 0.2 & 1.0 & $0.3-2.9$ \\
\hline ACTH $(\mathrm{pg} / \mathrm{ml})$ & 32 & 31 & 27 & 32 & $6-36$ \\
\hline Cortisol $(\mu \mathrm{g} / \mathrm{dl})$ & 14.2 & 13.8 & 12.3 & 11.8 & $3.0-15.2$ \\
\hline Progesterone $(\mathrm{ng} / \mathrm{ml})$ & 1.22 & 1.18 & 1.05 & 1.10 & $0.5^{-1.52}$ \\
\hline $\mathrm{DOC}(\mathrm{ng} / \mathrm{ml})$ & 1.64 & 1.68 & 0.29 & 0.26 & $0.03-0.33$ \\
\hline Corticosterone $(\mathrm{ng} / \mathrm{ml})$ & 3.99 & 4.01 & 3.07 & 2.89 & $0.21-8.48$ \\
\hline Aldosterone (pg/ml) & 62 & 58 & 35 & 54 & $35.7-240$ \\
\hline \multicolumn{6}{|l|}{ Urine } \\
\hline 17-OHCS (mg/day) & 5.2 & 5.1 & & & $1.9-6.1$ \\
\hline 17-KS (mg/day) & 3.6 & 3.4 & & & $3.1-8.8$ \\
\hline Metanephrine (mg/day) & 0.11 & & & & $0.01-0.3$ \\
\hline Normetanephrine (mg/day) & 0.19 & & & & $0.05-0.4$ \\
\hline
\end{tabular}

ACTH : adrenocorticotropic hormone, DOC : 11-deoxycorticosterone

Table 2a Effects of administration of furosemide and 2 hourupright posture

\begin{tabular}{lcc}
\hline Plasma & Before & 2 hour-upright \\
\hline Renin activity $(\mathrm{ng} / \mathrm{ml} / \mathrm{hr})$ & 0.1 & 0.1 \\
Aldosterone $(\mathrm{pg} / \mathrm{ml})$ & 68 & 61 \\
DOC $(\mathrm{ng} / \mathrm{ml})$ & 1.63 & 1.62 \\
\hline
\end{tabular}

Table 2b Daily profile and effects of administration of dexamethasone

$1 \mathrm{mg}$ of dexamethasone $(2300 \mathrm{~h})$

\begin{tabular}{|c|c|c|c|c|}
\hline \multirow[b]{2}{*}{ Plasma } & \multicolumn{4}{|c|}{$x_{10}$} \\
\hline & $06: 00 \mathrm{~h}$ & $12: 00 \mathrm{~h}$ & $18: 00 \mathrm{~h}$ & $\downarrow \quad 06: 00 \mathrm{~h}$ \\
\hline $\mathrm{ACTH}(\mathrm{pg} / \mathrm{ml})$ & 32 & 20 & 15 & 6 \\
\hline Cortisol $(\mu \mathrm{g} / \mathrm{dl})$ & 14.1 & 7.6 & 6.3 & 1 \\
\hline DOC $(\mathrm{ng} / \mathrm{ml})$ & 1.65 & 1.62 & 1.58 & 1.60 \\
\hline
\end{tabular}

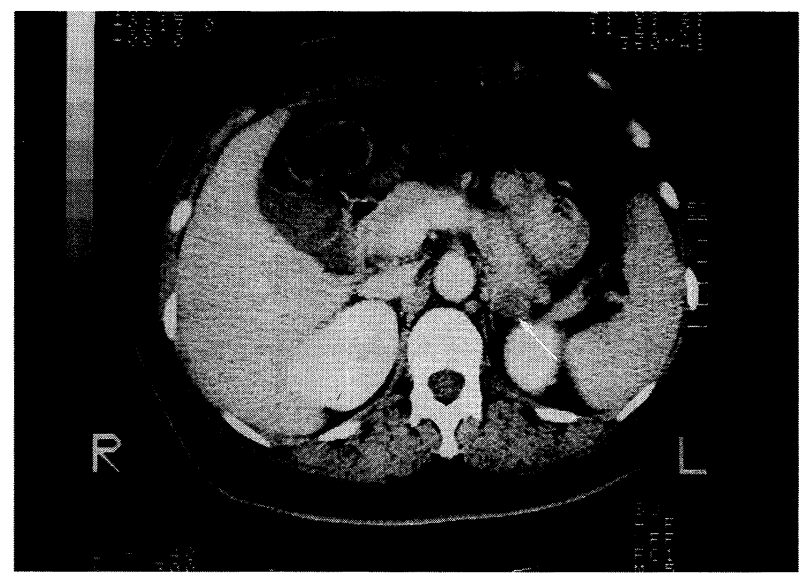

Fig. 1. Computed tomography revealed a round mass in the left adrenal region.
Table 2c Effects of acute administration of synthetic ACTH

\begin{tabular}{lccc}
\hline Plasma & Omin & 30mins & $60 \mathrm{mins}$ \\
\hline Cortisol $(\mu \mathrm{g} / \mathrm{dl})$ & 14.1 & 28.9 & 29.8 \\
Aldosterone $(\mathrm{pg} / \mathrm{ml})$ & 67 & 95 & 101 \\
DOC $(\mathrm{ng} / \mathrm{ml})$ & 1.64 & 1.65 & 1.64 \\
\hline
\end{tabular}

Table 2d Sampling data

1) inferior vena cava (Th12)

2 ) inferior vena cava (bifurcation)

3 ) right adrenal vein

4 ) right renal vein

5) left renal vein

6) left adrenal vein

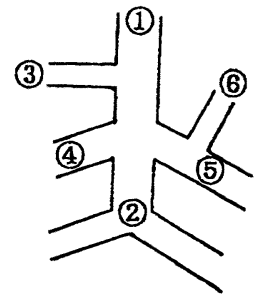

\begin{tabular}{lccc}
\hline & Cortisol $(\mu \mathrm{g} / \mathrm{dl})$ & $\mathrm{DOC}(\mathrm{ng} / \mathrm{ml})$ & Aldosterone $(\mathrm{pg} / \mathrm{ml})$ \\
\hline 1$)$ & 11.1 & 2.35 & 68 \\
$2)$ & 12.5 & 1.60 & 64 \\
$3)$ & 13.1 & 0.67 & 69 \\
$4)$ & 15.0 & 2.16 & 64 \\
$5)$ & 13.4 & 4.22 & 68 \\
$6)$ & 14.0 & 220.00 & 69 \\
\hline
\end{tabular}

Acute synthetic ACTH (Cortrosyn Z; $0.25 \mathrm{mg}$ ) administration increased cortisol and aldosterone levels, but did not increase DOC levels (Table 2c). ACTH was measured by the IRMA method, cortisol by fluorescence polarization immunoassay, PRA, progesterone, corticosterone, aldosterone or DOC by the RIA method and urinary catecholamine by the HPLC method. Although adrenal scintiscanning using ${ }^{123}$ I adosterol showed normal uptake, an abdominal computed tomography revealed a round mass in the left adrenal region (Fig. 1). Plasma DOC of the left adrenal vein was markedly elevated $(220.00 \mathrm{ng} / \mathrm{ml})$. Plasma levels of cortisol and aldosterone were almost 


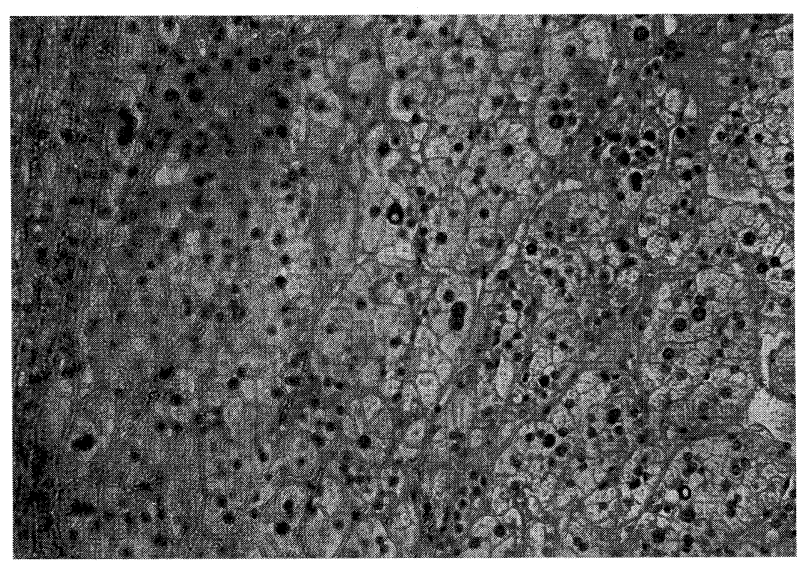

Fig. 2. The left adrenal tumor, encapsulated, consisted mainly of clear cells without cellular atypia in the adrenal cortex (Hematoxylin-Eosin $\times 100$ ).

unchanged in those sampling blood (Table 2d). Based on these findings, a left adrenal tumor producing DOC was suggested. Oral administration of spironolactone ( $150 \mathrm{mg}$, t.d.s. for 10 days) did not affect serum potassium level, urinary excretion of potassium level or blood pressure. After that, the left adrenal tumor $(11 \times$ $9 \times 8 \mathrm{~mm}$ ) was removed. Histologically, the encapsulated tumor consisted mainly of clear cells without cellular atypia in the adrenal cortex, a finding compatible to adrenocortical adenoma (Fig. 2). Her blood pressure, serum potassium, basal PRA and plasma DOC levels became normal after the operation.

\section{DISCUSSION}

The patient had clinical manifestation featured by hypertension, persistent hypokalemia and low level of PRA. PRA remained low following the stimulation of intravenous furosemide and 2 hour-upright position. Suppression of the renin system is a characteristic of mineralocorticoid excess ${ }^{1 \sim 3}$. However, all levels of plasma aldosterone, corticosterone, cortisol and urinary excretion of 17-KS and 17-OHCS were within normal range. These clinical and laboratory findings could exclude primary aldosteronism, Cushing's syndrome and adrenogenital syndrome. After removal of the left adrenal tumor, her blood pressure, serum potassium, PRA and plasma DOC levels were normalized. She had a DOC producing adrenocortical adenoma, although we failed to measure the DOC level in tumor tissue. The increment of DOC may produce the pathological state of mineralocorticoid excess, with hypertension, hypokalemia and suppression of PRA. Plasma ACTH and cortisol levels showed daily fluctuation and were inhibited with administration of dexamethasone. Acute synthetic ACTH administration increased the cortisol level, but did not increase the
DOC level. Although aldosterone secretion in patients with primary aldosteronism ${ }^{4,5)}$ and DOC secretion from an adrenocortical tumor ${ }^{2,3}$ are controlled by $\mathrm{ACTH}$, the DOC level showed independent secretion of ACTH control in our adrenocortical adenoma. Low response of the DOC level by administration of dexamethasone or synthetic ACTH has been shown in adrenocortical carcinoma $a^{6,7)}$. Cortisol or aldosterone levels are barely responded to synthetic ACTH in those cases, although the levels increased in our case. Oral administration of $150 \mathrm{mg}$ spironolactone could not satisfactorily control serum potassium level, urinary excretion of potassium level or blood pressure in the patient, although such easy control has been previously reported by other investigators ${ }^{8}$. It has been assumed that the DOC producing adrenocortical adenoma in the patient is more autonomous than previously reported case $^{2,3,8)}$.

\section{REFERENCES}

1) Cope CL, Loizou S. Deoxycorticosterone excretion in normal, hypertensive and hypokalemic subjects. Clinical Science 1975; 48: 97-105.

2) Kondo K, Saruta T, Saito T, et al. Benign deoxycorticosterone producing adrenal tumor. J A M A $1976 ; 236$ : 1042-1044.

3) Powell-Jackson JD, Calin A, Fraser R, et al. Excess deoxycorticosterone secretion from an adrenocortical carcinoma. Br Med J 1974; 2 : 32-33.

4) Kem DC, Weinberger MH, Gomez-Sanchez C, et al. Circadian rhythm of plasma aldosterone concentration in patients with aldosteronism. J Clin Invest 1973; 52: 2272-2277.

5) Schambelan M, Brust NL, Chang BCF, et al. Circadian rhythm and effect of posture on plasma aldosterone concentration in primary aldosteronism. J Clin Endocrinol Metab 1976; 43 : 115131.

6) Irony I, Biglieri EG, Perloff D, et al. Pathophysiology of deoxycorticosterone-secreting adrenal tumors. J Clin Endocrinol Metab 1987; 65: 836-840.

7) Makino K, Yasuda K, Okuyama M, et al. An adrenocortical tumor secreting weak mineralocorticoids. Endocrinol Jpn 1987; $34: 65-72$.

8) Ishikawa $S$, Saito $T$, Kaneko K, et al. Hypermineralocorticism without elevation of plasma aldosterone : deoxycorticosterone-producing adrenal adenoma and hyperplasia. Clinical Endocrinol $1988 ; 29: 367-375$. 